\title{
An Investigation on How University Students' View Lecturers' Usage of Speech Acts in ELT context
}

\author{
Mutiara Shasqia ${ }^{1}$ \& Aulia Anggraini ${ }^{2}$ \\ Dept. of English, Universitas Lancang Kuning, Pekanbaru. Riau \\ shasqiamutiara@yahoo.co.id
}

\begin{abstract}
ARTICLE HISTORY
Received : 2020-03-06

Revised : 2020-07-01

Accepted : 2020-07-21
\end{abstract}

\section{KEYWORDS}

Speech Act

University Lecturers

University Students

Perlocutionary Act

Illocutionary Act

\begin{abstract}
Teachers and lecturers alike understand that they must consciously use a variety of speech acts to force students to follow their instructions and be motivated to learn on their own. This paper reports the findings of a study designed to investigate the notion of the perlocutionary effect of university students in the classroom resulted from lecturers' illocutionary acts. The acts were then analyzed the illocutionary act of the lecturers' talk or speech during specific time using Austin's speech act theory. This present study built its investigation from data collection on both lecturers and university students through interview and field notes. This study manage to reveals that lecturers freely use speech acts of persuading, angering, and commanding. This study believes that illocutionary acts will still have happened in our interaction's life or communication in many-many context including classroom interaction between lecturer-students communication context.
\end{abstract}

\section{Introduction}

University classroom in English Language Teaching (ELT) context is a place where lecturers consciously use speech acts to make, practically force, students to understand what is being said. Not only is speech acts necessary to make students act as they are instructed, but also to convince the listeners to feel motivated by their personal thoughts to actually do what is being uttered (Weda, Samad, Patak, \& Fitriani, 2018). This present study is interested in studying university lecturers' illocutionary acts, which are acts we do in saying, that affect university students' perlocutionary acts, which are acts we do by saying, in classroom communication.

Communication is a process of delivering information (messages and ideas) from one or more person to another. In general, communication is made orally or verbally that can be understood by both participants (Rahman, 2016; Sihombing, 2019). In the classroom in which the language has very diverse functions. Communication functions both teachers and students in the classroom have transactional and interactional functions (Mendelson, 2018). Students in the transactional context have both academic needs (ability to make good grades) and interactional needs (feel affirmed as a person).

In the same way, the distinction between the roles of speakers and listeners in conversation is sensible and easy to make speakers talk, and listeners listen. It is much harder to distinguish the cognitive processes underlying speaking and listening. Shasqia (2020) asserts Theories of self-monitoring typically assume that monitoring during speaking involves the speech comprehension system, with speakers processing their phonological utterance plans as they would process external speech input (Licea-Haquet, VelásquezUpegui, Holtgraves, \& Giordano, 2019) or they assume monitoring processes that are internal to a speech planning system that is shared with the comprehension system.

Speech act shows when people make utterances such as apology, greeting, request, complaint, invitation, compliment, or refusal. The study of speech act is significant for people, accurately because it makes people comprehend the message discovered in every utterance. Speech acts play a role in making people understanding the messages contained in every word people hear and read (Gowasa, Radiana, \& Afifah, 2019). Austin (1975) introduced the concept of illocutionary acts and carefully distinguished them from illocutionary acts and perlocutionary effects. Locutionary acts include phonetic acts, phatic acts, and rhetic acts. Phonetic acts are acts of pronouncing sounds, phatic acts are acts of uttering words or sentences in accordance with the phonological and syntactic rules of the language to which they belong, and rhetic acts are acts of uttering a sentence with sense and more or less definite reference. Perlocutionary effects are, on the other hand, acts ascribed to the effect of uttering a sentence. 
The study of speech act has been done by the previous researcher in the different fields of communication. The researcher found the speech act classification illocutionary act, illocutionary act which are declarations, representatives, directives, expressive and types of sentences which are declarative is used, and it needs illocutionary acts is frequently realized in the declarative because the speaker tries to do something to the listeners through the speech (Saragi, Nuratika, Fransiska, Yolanda, \& Ardiyanti, 2019). Previous studies have been elaborate above and the difference of the earlier studies about speech act (Sbisà, 2018), so in this study, I focused on the "perlocutionary effect of Students in the classroom."

A perlocutionary act is an act performed by saying something, and not in saying something. Persuading, angering, inciting, comforting, and inspiring are often the perlocutionary effect of the utterance on the hearer, depending on specific circumstances. This is the effect on the hearer of what the speaker says. The perlocutionary act is the consequent effect of the utterance on the hearer or the overall aim of the utterance.

Perlocutinary act as the effect on the listener or the hearer means that the researcher can observe it by seeing how the students respond to the lecturer's utterance, indicating if and how they understand it. For example, "She was really hot because of the weather". Then, the teacher said to us, "your class is too hot," or a teacher asks the students to do the task. This utterance is called the illocutionary act. When it sees from basic meaning, it is just a statement, but in fact, it is asking students to do perlocutionary acts.

At this point, in delivering, the lecturer always uses the speech acts. The teacher implements the illocutionary act that eventually the students can understand the purpose of utterances so that it can be seen as the students' perlocutionary acts. Therefore, the researcher intends to investigate this study: a) How do the students deal with the perlocutionary act in their classroom interaction with the teachers, b) How do the teachers facilitate the students' perlocutionary effect in their interaction.

\section{Method}

This fieldwork study was carried out for approximately one week in 2018 in FKIP, Universitas Lancang Kuning, in December 2018. Since this research was conducted in the area of English language teaching, in this study, we focused on lecturer and students in the classroom to know the speech act, especially in the perlocutionary effect of students in the classroom and what's actually utterances that used in learning processing. Another consideration was that English students' interaction in the class there are illocutionary and perlocutionary.
The study employed observation field notes, student interviews, record or video to collect the data for the research question. The process of collecting data was continued until the researcher reached a point of data saturation. The gathered data was qualitatively analyzed and specifically focused on the identification and discussion of as student's deal with the perlocutionary act in their classroom interaction with the teacher and lecturer's facilitate the perlocutionary effect in their interaction and kinds of utterances or 5 general functions of speech act (declarative, representatives, commisives, directives and expressive) even we focused on the effect of utterances. Moreover, the researcher also used transcript speech act theory, such as the locutionary act, illocutionary force and the perlocutionary effect of the utterances.

\section{Results}

\subsection{How do students deal with the perlocutionary act in their classroom interaction with the lecturer?}

In the class, English students do some action when they get illocutionary from the teacher. Perlocutionary acts, speech acts are performed to produce a further effect on the hearer. Sometimes it may seem that perlocutionary acts do not differ from illocutionary acts very much. There is one crucial feature that tells them apart. There are two levels of success in performing illocutionary and perlocutionary acts as shown in the following excerpt 1.

\section{Excerpt 1}

Actually, Mr.Kurniawan is a good lecturer, we can be given dispensation if we don't finish yet about the submitted assignment, even we should make the commitment, we should submit the assignment based on the date that selected. It means that we are discipline, we receive the consequence or risk; maybe our score are not same with the students that collect the assignment on time. But we still et change.

(interview with s1)

from the interview, the student has a deal of perlocutionary act with the lecturer.and some utterance as shown in the following excerpt 2

\section{Excerpt 2}

(during interaction in the class the lecturer asks some questions to the students, and reminding about the task to collected)

L1 : oh yaa, I have asked you to post your English mix with your culture.where's the

Video, oke submit now, and I see on Facebook (illocutionary act ) 
S1. Already post, sir (students post their assignment on facebook and lecturer sees the assignment of LCD and they see together (perlocutionary effect)

(Audio transcript, 12 December 2018)

From the transcript audio from the lecturer and student's interaction so many things illocutionary that usually given by lecturer and students respond by laughing and make a joke as shown in the following excerpt 3

\section{Excerpt 3}

During the study, some phenomena happen in classroom activity, the lecturer explained about the materiel at that time. Usually, he explained by using combine language English-Indonesia, he taught by and forth around the class. During the study, he got the calling from his phone, and usually he made a job, sometimes he spoke faster, so that the students were difficult to understand.

(Field Note , 12 December 2018)

\subsection{How do the teachers facilitate the students' perlocutionary effect in their interaction?}

There are facilitates from the teacher to the students' perlocutionary effect in their interaction by giving dispensation or additional time, when the teacher gives illocutionary to the students and there is a perlocutionary of students, as shown in excerpt 4 .

\section{Excerpt 4}

(teacher are reminding about the assignment to the students)

\section{L1 : how about other?}

$\mathrm{S}$ : not yet sir, you said in the middle of December

L1 : what's date ? oh okey before 20 December you should submit your project and project posting on Facebook.

(Audio Transcript, 12 December 2018)

\section{Excerpt 5}

At 10:30 lecturer came to the room, he was greeting to the students and directly remember about for next week and also examination. Lecturer asked to submit our assignme

nt, not the previous week. Some students answered that they had already finished the task, and some of the students hadn't already yet. Because of misunderstanding about the date of submitting. and lecturer gave dispensation and remember the date to submit, after expalained about previous material and assignment, the lecturer was going to new materi at that time.

(Observation Field Note, 14 December 2018)

In excerpt 5 is additional of teachers facilitate to the students of perlocutionary effect by using some ways such as dispensation, additional time and based on the excerpt above show about the deal of students and teacher's interaction in the class.

\section{Discussion}

Perlocutionary happens whenever and wherever people are as long as they are in an interaction with another person, specifically in classroom interaction, it will make some discussion consists of illocutionary and perlocutionary in their communication or teacher and student's interaction. From what has been observed in the classroom's conversations, the lecturer usually does illocutionary acts to the students, and automatically, there is an illocutionary response. The students give perlocutionary by action when they talk, discuss, or even debate with the lecturer. These findings are in line with the typical classroom interaction informal education (Derin \& Hamuddin, 2019; Lauren \& Cendy, 2020).

The findings prove that speech act theory contributes to the theory of linguistic universals in formulating the necessary and universal laws governing the successful performance and satisfaction of all kinds of illocutionary acts in language use and comprehension. The logical form of illocutionary acts imposes certain formal constraints on logical structure of a possible natural language as well as on the mind of competent speakers that happened in our interaction.

Moreover, if linguistic competence is the ability to perform and understand illocutionary acts, then the competent speaker and hearers must have certain mental states and abilities which are generally and traditionally related to the faculty of reason. In other words, students' linguistic competency seems to be hand-to-hand with their interactional politeness and linguistic appropriation (Hamuddin, Syahdan, Rahman, Rianita, \& Derin, 2019; Heyd \& Puschmann, 2017). Language can be a medium to link individuals with society (Putri, 2020). The language use offers the largest range of features and the most easily adaptable ones for identification.

As this study revealed, perlocutionary is a thing that people do when they hear illocutionary acts. Not only the teacher to the students, between student to student will be happened perlocutionary in the class to illustrate the findings. Austin's original formulation of speech act theory a careful distinction was drawn between illocutionary acts as conventional acts having 
conventional effects, on the one hand, and on the other the causal, perlocutionary effects that these acts could bring about (independently of the illocutionary act performed and the speaker's intentions;. In interactional pragmatics, however, accountability seems to be broadened to cover a vast array of practical consequences that a meaning-action may have, and that as such remain to a certain extent underdetermined (Siumarlata, 2017). The standards of assessment are taken as given within the social order, notwithstanding Austin's nice distinction between an act that is performed in accordance to a conventional procedure and a causal effect.

In relation to the findings, as to illustrate the perlocutionary effect, such logical reasoning to the common identified about the perlocutionary effect of students in classroom-based on observation, every illocutionary act there is a perlocutionary effect from hearer or hearer response as this is found clearly in this study.

\section{Conclusion}

Regarding the perlocutionary effect of students in classroom assessment methods and objectives as the reflections of communication activities, the English students were identified to apply some perlocutionary utterance or assessment methods, which eventually also parts of their communication activities covering illocutionary act and perlocutionary effect. Based on this case, this present study can said that many kinds of perlocutionary effect or students' respond and kinds of the deal of perlocutionary to teacher's illocutionary and also, perlocutionary will have happened in our interaction's life or communication, one of it in classroom interaction between lecturer-students communication.

At present day, the challenge of typical qualitative indirect perlocutionary effects of students in classroom assessment use has been promoted and advocated in numerous inquiries principally through self-assessment, i.e., portfolios, journals, etc. It is due to such considerations that are relying on selfassessment can be a positive factor in encouraging greater effort in analyzing, comparing, and reflecting. Of course, the illocutionary act frequently realized in the declarative because the speaker tries to inform something to the listeners through the speech and so many perlocutionary effect that happed in our communication. The researcher suggests that the next researchers or writers observe the perlocutionary act to make more in-depth analysis in speech act and find another research object to analyze to show that speech act theory can be implemented in many kinds of social media or non-verbal communication.

\section{References}

Austin, J. L. (1975). How to do things with words (Vol. 88). Oxford university press.

Derin, T., \& Hamuddin, B. (2019). Foreign Language Classroom Anxiety, and Enjoyment During Study Abroad: A Review of Selected Paper. Lisan: Jurnal Bahasa dan Linguistik, 8(2), 76-82.

Gowasa, N. S., Radiana, S. P., \& Afifah, N. (2019). A Study on the Use of Speech Acts: A Review of Selected Paper. ELSYA: Journal of English Language Studies, 1(2).

Hamuddin, B., Syahdan, S., Rahman, F., Rianita, D., \& Derin, T. (2019). Do They Truly Intend to Harm Their Friends?: The Motives Beyond Cyberbullying among University Students. International Journal of Cyber Behavior, Psychology and Learning (IJCBPL), 9(4), 32-44.

Heyd, T., \& Puschmann, C. (2017). Hashtagging and functional shift: Adaptation and appropriation of the. Journal of Pragmatics, 116, 51-63.

Lauren, C., \& Derin, T. (2020). Systematic Review: Where is Current Research on Conversational Analysis?. ELSYA: Journal of English Language Studies, 2(2), 12-17.

Licea-Haquet, G. L., Velásquez-Upegui, E. P., Holtgraves, T., \& Giordano, M. (2019). Speech act recognition in Spanish speakers. Journal of Pragmatics, 141, 44-56.

Mendelson, M. A. (2018). Understanding Functions in Learner Speech. The TESOL Encyclopedia of English Language Teaching, 1-7.

Putri, S. D. (2020). Language Comparison Between Swahili and Malay Languages with Semantic and Pragmatic Problems. REiLA: Journal of Research and Innovation in Language, 2(1).

Rahman, F. (2016). The Strategy of Teaching Literature through Language-based Methods: A Communicative Approach. Annual Seminar on English Language Studies 2016, (1), 156-170.

Saragi, V., Nuratika, S., Fransiska, F., Yolanda, M., \& Ardiyanti, N. (2019). A Review of Some Speech Act Theories Focusing on Speech Acts by Searle (1969). ELSYA: Journal of English Language Studies, 1(2), 60-68.

Sbisà, M. (2018). Varieties of speech act norms. In Normativity and variety of speech actions (pp. 23-50). Brill Rodopi. 
Shasqia, M. (2020). Teaching Narrative Text in Junior High School: Digital Story Telling in English as a Foreign Language (EFL) Context. Utamax: Journal of Ultimate Research and Trends in Education, 2(1).

Sihombing, I. C. (2019). Theoretical Perspectives of Discursive Phenomena: DA and Ethnomethodologically DA. REiLA: Journal of Research and Innovation in Language, 1(1), 3538.

Siumarlata, V. (2017). Analysis of Interactional And Transactional Language Used by The English Lecturers In Learning Process At English Department of FKIP UKI Toraja. Jurnal Keguruan dan Ilmu Pendidikan, 6(2), 1497-1520.

Weda, S., Samad, I. A., Patak, A. A., \& Fitriani, S. S. (2018). The Effects of self-efficacy belief, motivation, and learning strategies on students' academic performance in English in higher education. The Asian EFL Journal Quarterly, 20(9.2), 140-168. 